\title{
Front Matter: Volume 7460
}

, "Front Matter: Volume 7460," Proc. SPIE 7460, Lidar Remote Sensing for Environmental Monitoring X, 746001 (1 September 2009); doi:

$10.1117 / 12.844700$

SPIE Event: SPIE Optical Engineering + Applications, 2009, San Diego, California, SPIE. United States 


\section{PROCEEDINGS OF SPIE}

\section{Lidar Remote Sensing for Environmental Monitoring X}

Upendra N. Singh

Editor

3 August 2009

San Diego, California, United States

Sponsored and Published by

SPIE

Volume 7460

Proceedings of SPIE, 0277-786X, v. 7460 
The papers included in this volume were part of the technical conference cited on the cover and title page. Papers were selected and subject to review by the editors and conference program committee. Some conference presentations may not be available for publication. The papers published in these proceedings reflect the work and thoughts of the authors and are published herein as submitted. The publisher is not responsible for the validity of the information or for any outcomes resulting from reliance thereon.

Please use the following format to cite material from this book:

Author(s), "Title of Paper," in Lidar Remote Sensing for Environmental Monitoring $X$, edited by Upendra N. Singh, Proceedings of SPIE Vol. 7460 (SPIE, Bellingham, WA, 2009) Article CID Number.

ISSN 0277-786X

ISBN 9780819477507

Published by

SPIE

P.O. Box 10, Bellingham, Washington 98227-0010 USA

Telephone +1 3606763290 (Pacific Time) · Fax +1 3606471445

SPIE.org

Copyright (C) 2009, Society of Photo-Optical Instrumentation Engineers

Copying of material in this book for internal or personal use, or for the internal or personal use of specific clients, beyond the fair use provisions granted by the U.S. Copyright Law is authorized by SPIE subject to payment of copying fees. The Transactional Reporting Service base fee for this volume is $\$ 18.00$ per article (or portion thereof), which should be paid directly to the Copyright Clearance Center (CCC), 222 Rosewood Drive, Danvers, MA 01923. Payment may also be made electronically through CCC Online at copyright.com. Other copying for republication, resale, advertising or promotion, or any form of systematic or multiple reproduction of any material in this book is prohibited except with permission in writing from the publisher. The CCC fee code is 0277-786X/09/\$18.00.

Printed in the United States of America.

Publication of record for individual papers is online in the SPIE Digital Library.

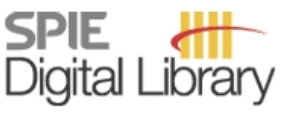

SPIEDigitalLibrary.org

Paper Numbering: Proceedings of SPIE follow an e-First publication model, with papers published first online and then in print and on CD-ROM. Papers are published as they are submitted and meet publication criteria. A unique, consistent, permanent citation identifier (CID) number is assigned to each article at the time of the first publication. Utilization of CIDs allows articles to be fully citable as soon they are published online, and connects the same identifier to all online, print, and electronic versions of the publication. SPIE uses a six-digit CID article numbering system in which:

- The first four digits correspond to the SPIE volume number.

- The last two digits indicate publication order within the volume using a Base 36 numbering system employing both numerals and letters. These two-number sets start with 00, 01, 02, 03, 04 , $05,06,07,08,09,0 A, 0 B \ldots$. OZ, followed by 10-1Z, 20-2Z, etc.

The CID number appears on each page of the manuscript. The complete citation is used on the first page, and an abbreviated version on subsequent pages. Numbers in the index correspond to the last two digits of the six-digit CID number. 


\section{Contents}

$\checkmark \quad$ Conference Committee

\section{SESSION 1 NEW LIDAR TECHNOLOGY AND TECHNIQUES}

746004 Wavelength beam combining of quantum cascade laser arrays for remote sensing [7460-03]

B. G. Lee, Harvard Univ. (United States); J. Kansky, A. K. Goyal, MIT Lincoln Lab. (United States); C. Pflügl, L. Diehl, M. A. Belkin, Harvard Univ. (United States); A. Sanchez, MIT Lincoln Lab. (United States); F. Capasso, Harvard Univ. (United States)

746005 Design and testing of a compact diode-laser-based differential absorption lidar (DIAL) for water vapor profiling in the lower troposphere [7460-04]

A. R. Nehrir, K. S. Repasky, J. L. Carlsten, Montana State Univ. (United States)

746006 Path-averaged atmospheric $\mathrm{CO}_{2}$ measurement using a $1.57 \mu \mathrm{m}$ active remote sensor compared with multi-positioned in situ sensors [7460-05]

D. Sakaizawa, S. Kawakami, M. Nakajima, Japan Aerospace Exploration Agency (Japan); Y. Sawa, H. Matsueda, Meteorological Research Institute (Japan); K. Asai, Tohoku Institute of Technology (Japan); S. Kameyama, M. Imaki, Y. Hirano, S. Ueno, Mitsubishi Electric Corp. (Japan)

746007 Skeleton-based botanic tree diameter estimation from dense LiDAR data [7460-06] A. Bucksch, R. Lindenbergh, M. Menenti, M. Z. Rahman, Delft Univ. of Technology (Netherlands)

\section{SESSION 2 DOPPLER LIDAR}

746009 VisibleWind: a rapid-response system for high-resolution wind profiling [7460-08]

T. Wilkerson, B. Bradford, A. Marchant, C. Wright, T. Apedaile, E. Fowles, A. Howard,

T. Naini, Utah State Univ. (United States)

7460 OA Characterization of high resolution range and Doppler LADAR [7460-09]

B. C. Flores, B. Verdin, The Univ. of Texas at El Paso (United States)

\section{SESSION 3 AEROSOL AND CLOUD OBSERVATIONS}

7460 OE Comparisons of aerosol-cloud observations between a ground-based Raman-Mie lidar and CALIPSO over U.S. East Coast [7460-13]

Y. Wu, B. Herman, B. Gross, F. Moshary, S. Ahmed, The City College of New York (United States) 
POSTER SESSION

7460 OG Using MIE Raman S ratio lidar measurements to explore cloud droplet properties and the aerosol indirect effect [7460-12]

S. Chaw, Y. Wu, E. Garofalo, B. Gross, F. Moshary, S. Ahmed, The City College of New York (United States)

$7460 \mathrm{OH} \quad$ CMAQ validation of optical parameters and PM2.5 based on lidar and sky radiometers: a sensitivity study of optical parameters to hygroscopic aerosols [7460-15]

D. V. Vladutescu, E. Garofalo, B. Gross, F. Moshary, S. Ahmed, The City College of New York (United States)

Author Index 


\title{
Conference Committee
}

\author{
Conference Chair
}

Upendra N. Singh, NASA Langley Research Center (United States)

Program Track Chair

Allen H.-L. Huang, University of Wisconsin, Madison (United States)

Program Committee

Farzin Amzajerdian, NASA Langley Research Center (United States)

Kazuhiro Asai, Tohoku Institute of Technology (Japan)

Theresa J. Axenson, Lockheed Martin Missiles and Fire Control (United States)

Timothy J. Carrig, Lockheed Martin Coherent Technologies (United States)

Floyd E. Hovis, Fibertek, Inc. (United States)

Achuthan Jayaraman, National Atmospheric Research Laboratory (India)

George J. Komar, NASA Goddard Space Flight Center (United States)

Shiv K. Sharma, University of Hawai'i (United States)

Jinxue Wang, Raytheon Company (United States)

Thomas D. Wilkerson, Space Dynamics Laboratory (United States)

David M. Winker, NASA Langley Research Center (United States)

\section{Session Chairs}

$1 \quad$ New Lidar Technology and Techniques

Upendra N. Singh, NASA Langley Research Center (United States)

2 Doppler Lidar

George J. Komar, NASA Goddard Space Flight Center (United States)

3 Aerosol and Cloud Observations

Thomas D. Wilkerson, Space Dynamics Laboratory (United States) 
Downloaded From: https://www.spiedigitallibrary.org/conference-proceedings-of-spie on 26 Apr 2023

Terms of Use: https://www.spiedigitallibrary.org/terms-of-use 